\title{
Breastfeeding exclusively and iron deficiency anemia during the first 6 months of age
}

\author{
Rosa F.S.V. Marques ${ }^{1}$, José A.A.C. Taddel², Fábio A. Lopez ${ }^{3}$, Josefina A.P. Braga** \\ 1Pediatrician, Professor, Department of Integral Health at the State University of Pará (UEPA), Pará, Brazil. \\ 2Pediatrician, Associate Professor, Department of Pediatrics at Escola Paulista de Medicina, Federal University of São Paulo (EPM-Unifesp), São Paulo, Brazil \\ 3Pediatrician, Full Professor, Department of PEdiatrics at Escola Paulista de Medicina, Federal University of São Paulo (EPM-Unifesp), São Paulo, Brazil \\ ${ }^{4}$ Pediatrician, Adjunt Professor, Department of Pediatrics at Escola Paulista de Medicina, Federal University of São Paulo (EPM-Unifesp), São Paulo, Brazil
}

Study conducted by the Department of Nutriology and the Department of Pediatric Specialties at Escola Paulista de Medicina, Federal University of São Paulo; and the Exclusive Breastfeeding Promotion/Support Program, Belém, Pará.

Article submitted: 09/03/12 Accepted for publication: 07/08/13

Correspondence Rua Dr. Diogo de Faria, 307 CEP: 04037-000 -

São Paulo/SP - Brazil

Phone: +55 11 5539-1093

pellegrini.braga@unifesp.br

http://dx.doi.org/10.1590/1806-9282.60.01.006

Conflict of interest: none

\section{SUMmaRY}

Objective: The objective was to determine the prevalence of iron deficiency and iron deficiency anemia among exclusively breastfed infants from one to six months of life and to identify associated risk factors.

Methods: This is a cohort study of the hemoglobin and serum ferritin levels of 102 healthy full-term infants, weighing more than 2500 grams (5.5 pounds) at birth, evaluated for growth development and supported to promote exclusive breastfeeding. Hemoglobin and ferritin levels were measured in the first, fourth, and sixth months of life. The hemoglobin and ferritin levels of the mothers were also measured in the first month postpartum.

Results: At four months, 5.7\% presented iron deficiency and 3.4\% had iron deficiency anemia. At six months, the percentage of children with iron deficiency increased more than four times, reaching $26.1 \%$, while iron deficiency anemia was present in $23.9 \%$ of the infants studied. Iron deficiency at six months of age was significantly correlated to growth velocity.

Conclusion: According to the results of this study, exclusive breastfeeding protects infants from iron deficiency and iron deficiency anemia for the first four months of life. After this age, in accordance with the literature, the findings of this study demonstrated an increase in anemia and iron deficiency rates, adding to evidence that supports the monitoring of iron levels in exclusively breastfed children presenting higher weight gains beginning at four months of age.

Key words: breastfeeding, hemoglobin, iron deficiency, anemia, infants.

\section{INTRODUCTION}

Iron deficiency is the most common and widespread nutritional disorder, occurring both in developed and developing countries. It affects a higher number of women in reproductive age and more than $40 \%$ of children in developing countries. ${ }^{1,2}$ Cognitive or behavioral deficits in infants with mild iron deficiency anemia have also been described. ${ }^{3}$ The minimum daily requirement for iron is based on body weight, and it is proportional to growth velocity. ${ }^{4-6}$

Although breast milk has a relatively small amount of iron, its absorption is high, especially when babies are breastfed exclusively in the first 6 months after birth. ${ }^{4,5}$ The first six months of life is the phase in which the child's feeding consists predominantly of milk. Human milk is recognized as the best form of nutrition due to its ideal balance of nutrients. ${ }^{4-6}$

This fact can be confirmed not only in the general literature, but also in a previous publication that enrolled the same sample of newborns included in the present study. The results showed that all exclusively breastfed children doubled their birth weight before the $4^{\text {th }}$ month of age and reached normal weight at 6 months. ${ }^{6}$ Nevertheless, regarding the status of iron, the Cochrane review reports that the scarceness of data of the compiled studies, at least in developing countries where iron stores may be suboptimal, suggests that exclusive breastfeeding up to 6 months without iron supplementation may compromise the hematologic status of children. ${ }^{4}$ 
A public service that promotes and encourages exclusive breastfeeding in Belém, state of Pará, Brazil, made this study possible. The objective was to determine the prevalence and risk factors of iron deficiency (ID) and iron deficiency anemia (IDA) in fully breastfeed infants at 1,4 , and 6 months of age.

\section{Methods}

This was a cohort study of hemoglobin and serum ferritin concentrations among infants enrolled in the Exclusive Breastfeeding Program, which was created to support mothers who pursued prenatal care at a public center for maternal, child, and adolescent care in the State of Pará, Brazil. The program specialized in promoting and protecting breastfeeding. During the medical visit, the program offers guidance on adequate breastfeeding techniques with the aim of reducing most of the causes that contribute to early weaning. This is an educational program comprised of multidisciplinary professionals in which mothers attend lectures about the benefits of breastfeeding and the relevance of breastfeeding exclusively in the first 6 months.

The study was conducted between February 2000 and January 2001, with an initial sample of 184 full-term infants with gestational age between 37 and 42 weeks, born weighing 2500 grams (5.5 pounds) or more, and presenting no complications in the perinatal period. The study ended with 102 infants. Losses during follow-up were due to the abandonment of exclusive breastfeeding $(\mathrm{n}=82)$ and the absence of the child to run the tests at scheduled periods $(n=14)$. To control for selection bias, the distributions of birth weight categories and sex were compared for drop-out and remaining groups, showing no statistical significance.

Infants were examined monthly for measurements of weight and height and for support in maintaining exclusive breastfeeding until the 6 th month of age. Given that they did not present any symptoms of acute infections, blood samples were collected on $26 \pm 5,124 \pm 5$, and $184 \pm 5$ days of age. None of the children received iron supplements. Hemoglobin and ferritin serum concentrations were collected by trained personnel using disposable materials, always in the morning and at the same laboratory, independently of fasting. Venous blood was collected from peripheral cubital/radial by vein puncture into tubes containing EDTA, and the plasma was separated and stored at $-20^{\circ} \mathrm{C}$ until analyzed. Hemoglobin analysis was immediately run using the cianometahemoglobin method with a Coulter device, model T890. After all samples had been collected, the plasma ferritin con- centration was analyzed using immunoenzymatic ELFA (Enzyme Linked Fluorescent Assay).

Measurements of hemoglobin at the $1^{\text {st }}$ and $6^{\text {th }}$ months of age were performed in 102 infants, and in 101 at the $4^{\text {th }}$ month. Serum ferritin was measured at the $1^{\text {st }}$, $4^{\text {th }}$, and $6^{\text {th }}$ months in 102,87 , and 88 infants, respectively. Regarding the omitted tests, one in the $4^{\text {th }}$ month was due to the absence of the child for blood sample collection; the remaining was due to technical problems in freezing and storage.

For categorical analyses, iron deficiency (ID) was defined as a plasma ferritin concentration $<10 \mathrm{ng} / \mathrm{mL}^{7}$, and anemia as a hemoglobin concentration $<10.5 \mathrm{~g} / \mathrm{dL}$ in the $1^{\text {st }}$ and $4^{\text {th }}$ months ${ }^{8}$ and $<11 \mathrm{~g} / \mathrm{dL}$ in the $6^{\text {th }}$ month. ${ }^{3}$ Iron deficiency anemia (IDA) was defined as ID plus anemia. Weight gain from birth to 6 months of age was categorized using 2 cut-off points: the WHO mean weight gain, and the mean weight gain for the study sample, both considering males and females.

As for mothers, hemoglobin and ferritin measurements were performed in the $1^{\text {st }}$ month postpartum. A hemoglobin cutoff point of $<12.0 \mathrm{~g} / \mathrm{dL}$ was adopted for the diagnosis of anemia, ${ }^{2,9}$ and serum ferritin counts $<12 \mathrm{ng} / \mathrm{mL}$ for depleted iron, based on World Health Organization (WHO) criteria. ${ }^{7}$

\section{Research Ethics}

This protocol was analyzed and approved by the Research Ethics Committee in of Federal University of São Paulo.

\section{Statistical analysis}

For the statistical analyses, SPSS for Windows (SPSS Inc., Chicago, IL, USA) was used. The distributions of categorical variables were analyzed by chi-square test or Fisher's exact test, if applicable.

\section{Results}

Among the 184 low-income children enrolled in the program, 82 were excluded for not meeting the requirement of 6 months of exclusive breastfeeding. Of the 102 children who completed the study, $13.7 \%$ did not undergo measurement of serum ferritin 4 and 6 months after birth. For the 88 mothers of children who made up the final sample, the mean age was 21 years, $68.6 \%$ were primiparous, and $64.7 \%$ had natural delivery. They had an average of 8 to 9 years of education, all of them attended prenatal care, and $85.3 \%$ reported the use of iron supplements for some time during pregnancy.

IDA was present in $15.7 \%$, and ID occurred in $16.7 \%$ of the mothers being studied. No correlation was found 
between hemoglobin levels of mother and child in the first 6 months of age ( $\mathrm{p}=0.6073-$ Pearson linear correlation).

Table 1 shows distributions of serum ferritin and hemoglobin concentrations for infants in the $1^{\text {st }}, 4^{\text {th }}$, and $6^{\text {th }}$ months of age and for their mothers. The ferritin mean for the infants dropped 10 times during study follow-up, from 252 in the 1 st month to $24 \mathrm{ng} / \mathrm{mL}$ in the $6^{\text {th }}$ month of age.

Distributions of children presenting ID and IDA according to age and sex are presented in Table 2. Three new cases of IDA were identified in the $4^{\text {th }}$ month observation, resulting in a 2 -month incidence rate of $3.4 \%$ $(3 / 87 * 100)$, while 15 new cases of IDA were identified in the $6^{\text {th }}$ month, showing a 2 -month incidence rate of $17.0 \%$ $(15 / 88 * 100)$.

Among the studied risk factors, sex, birth weight, mothers' ID, and IDA, were not significantly associated with children's ID and IDA at 6 months of age. Only weight gain from birth until 6 months of age, when above the sample mean, was significantly associated with ID (see Table 3).

\section{Discussion}

Exclusive breastfeeding during the first 6 months of age turned out to be a challenging requirement, restricting the number of participants. The challenge was even greater due to the need of collecting 3 blood samples from the children to describe variations in iron profiles and associated factors. ${ }^{4}$ Despite the high drop-out rate, similar proportions of birth weight categories and sex for both drop-outs and remaining groups show that withdrawals might not have introduced significant selection bias.

Although most of the mothers were young adults, had attended pre-natal care, and studied for at least 8 to 9 years, the use of iron prophylaxis during pregnancy was irregular. Consequently, we observed that $15.6 \%$ of mo- thers had IDA and $16.6 \%$ had ID, results that indicate the need for diffusion of adequate knowledge of the physiologic changes that occur in a woman's body during pregnancy and the need for iron supplementation in a more rational and critical way. ${ }^{7}$

No association was found in this study between the body iron status of mothers and those of their children at 6 months of age. Paiva et al. also observed that iron concentration in pregnant women with iron deficiency or mild/severe anemia had not significantly influenced their children's iron concentrations. ${ }^{10}$

Support for breastfeeding is an effective preventive measure. It protects against iron deficiency-related anemia because, in despite of the low iron concentration in the mothers' milk, the bioavailability of iron is high.,11 It is known that exclusive breastfeeding protects children from IDA, but increasingly, studies report that the iron reserves received by the child in the last trimester of pregnancy runs out between 4 and 6 months after birth, even in exclusively breastfed lactents. ${ }^{11-13}$

Risk factors for IDA in the $6^{\text {th }}$ month of age, such as maternal anemia, underweight, sex, weight gain, and umbilical cord clamping time are described in the literature. ${ }^{14,15}$ As reported by some authors, late-timing of cord clamping, as compared to immediate clamping, might be associated with better hemoglobin values, higher stores of iron at 6 months of age, and lower incidence of anemia. ${ }^{15-17}$

Unfortunately, time of umbilical cord clamping is not registered during labor by health professionals in Brazil, which makes it impossible to control for such potential bias.

Yang et al. (2009) pooled data from 6 randomized clinical trials conducted between 1994 and 2004, 2 in Ghana, 2 in Honduras, 1 in Mexico, and 1 in Sweden, with a total of 404 infants who were exclusively breastfed, to study IDA risk factors. They observed that the occurrence of anemia in exclusively breastfed children at 6 months

TABLE 1 Distribution of hemoglobin $(\mathrm{g} / \mathrm{dL})$ and serum ferritin $(\mathrm{ng} / \mathrm{mL})$ for children of different ages and their mothers at first month postpartum

\begin{tabular}{|c|c|c|c|c|c|c|c|c|}
\hline & \multicolumn{2}{|l|}{$1^{\text {st }}$ month } & \multicolumn{2}{|l|}{$4^{\text {th }}$ month } & \multicolumn{2}{|l|}{$6^{\text {th }}$ month } & \multicolumn{2}{|l|}{ Mothers } \\
\hline & Hemoglobin & Ferritin & Hemoglobin & Ferritin & Hemoglobin & Ferritin & Hemoglobin & Ferritin \\
\hline $\mathrm{N}$ & & 102 & 102 & 101 & 87 & 102 & 88 & 102 \\
\hline Mean & 11.64 & 252 & 10.04 & 56 & 10.08 & 24 & 11.83 & 53 \\
\hline Median & 11.40 & 222 & 10.10 & 39 & 10.00 & 17 & 12.25 & 37 \\
\hline $\begin{array}{l}\text { Standard } \\
\text { deviation }\end{array}$ & 1.80 & 139 & 0.97 & 56 & 0.92 & 24 & 1.78 & 54 \\
\hline Minimum & 8.70 & 27 & 7.60 & 3 & 7.20 & 2 & 7.10 & 3 \\
\hline Maximum & 18.20 & 726 & 13.00 & 329 & 13.30 & 170 & 15.60 & 338 \\
\hline
\end{tabular}


of age and birth weight > 2500 grams (5.5 pounds) was low in male infants and those with birth weights between 2500-2999 $\mathrm{g}$ had higher risks for ID and IDA. ${ }^{14}$

The prevalence of ID ranged from $6 \%$ in Sweden to $37 \%$ in Ghana, while the prevalence of IDA ranged from $2 \%$ in Sweden to $16 \%$ in Ghana. ${ }^{14}$ In this study, the prevalence of ID can be compared to the rate in Honduras (25\%), and the IDA frequency 6 months after birth was greater than that found in Ghana.

Domellöf et al. (2002) suggested reassessment of the laboratory criteria for defining ID and IDA in infants, proposing a hemoglobin cut-off point for exclusively breastfed babies of $<10.5 \mathrm{~g} / \mathrm{L}$ at 4 and 6 months of age. ${ }^{8}$

Regarding risk factors, only weight gain above the sample mean was associated with ID 6 months after birth, showing that children growing at higher rates are more susceptible to ID. This is information that could help health planners and clinical practitioners target higherrisk groups of infants.

Thus, in this study, breastfeeding protected children from ID/IDA until the $4^{\text {th }}$ month of age, which is in accordance with the literature. ${ }^{11,18}$ This fact indicates the need for surveillance by the $4^{\text {th }}$ month after birth in order to identify children in need of iron supplementation.

Additional evidence to support such a recommendation is a previous Brazilian cohort study in which Torres et al. (2006) observed $37.5 \%$ of anemia in low-income, exclusively breastfed infants. ${ }^{19}$ The Brazilian Pediatrics Society already recommends that children born at term with more than 2500 grams (5.5 pounds) and exclusively breastfed should get iron supplements after 6 months, and that children who began the weaning process earlier than 6 months and who do not receive enriched formulas should also receive iron supplements. ${ }^{20}$ Thus, the only necessary change would be to advise pediatricians to consider IDA when healthy, fully breastfed babies reach 4 instead of 6 months of age.

\section{Conclusion}

In conclusion, in this study, exclusive breastfeeding protects children from ID/IDA in the first 4 months of life. After this period, in agreement with the literature, the findings of this study demonstrated an increase in anemia and iron deficiency rates, adding to evidence that supports the monitoring of iron levels in exclusively breastfed children presenting higher weight gains beginning at 4 months of age. ${ }^{18,21}$

\section{Resumo}

Aleitamento materno exclusivo e anemia ferropriva nos seis primeiros meses de vida.
Objetivo: Determinar a prevalência da deficiência de ferro e anemia ferropriva em crianças, de um aos seis meses de vida, alimentadas exclusivamente ao seio materno e identificar os fatores de risco associados.

Métodos: Estudo de coorte dos valores de hemoglobina e ferritina sérica de 102 lactentes a termo, saudáveis, nascidos com peso maior que $2500 \mathrm{~g}$, acompanhados quanto ao crescimento e desenvolvimento e com apoio à promoção do aleitamento materno exclusivo. Hemoglobina e ferritina sérica foram dosadas no primeiro, quarto e sexto mês de vida. Hemoglobina e ferritina sérica também foram dosadas nas mães no primeiro mês pós-parto.

Resultados: Aos quatro meses, 5,7\% dos lactentes apresentaram deficiência de ferro e 3,4\%, anemia ferropriva. Aos seis meses, o percentual de crianças com deficiência de ferro aumentou mais de quatro vezes, atingindo a proporção de $26,1 \%$, enquanto a anemia ferropriva esteve presente em $23,9 \%$ dos lactentes da amostra. A deficiência de ferro aos seis meses foi associada significativamente com maior ganho ponderal.

Conclusão: Neste estudo, o aleitamento materno exclusivo protegeu as crianças da deficiência de ferro e da anemia ferropriva nos primeiros quatro meses de vida. Após essa idade, concordando com dados da literatura, esse estudou mostrou aumento na taxa de anemia e da deficiência de ferro, o que fornece mais uma evidência para apoiar a vigilância do estado do ferro, a partir dos quatro meses, para crianças em aleitamento materno exclusivo e que apresentem ganho de peso acima da média.

Unitermos: aleitamento materno, hemoglobina, deficiência do ferro, anemia, bebês.

\section{References}

1. World Health Organization. Micronutrient deficiencies. Iron deficiency anaemia: the challenge. Geneva: WHO; 2004

2. World Health Organization. Iron deficiency anaemia: assessment, prevention and control. A guide for programme managers. Geneva: WHO/UNICEF/ UNU; 2001.

3. Lozoff B, Beard J, Connor J, Barbara F, Georgieff M, Schallert T. Long-lasting neural and behavioral effects of iron deficiency in infancy. Nutr Rev. 2006; 64:S34-43.

4. World Health Organization. The optimal duration of exclusive breastfeeding. A systematic review. Kramer MS, Kakuma R, editors. Geneva: WHO, 2002

5. Heinig MJ, Dewey KG. Health advantages of breastfeeding for infants: a critical review. Nutr Res Rev. 1996;9:89-110.

6. Marques RF, Lopez FA, Braga JA. Growth of exclusively breastfed infants in the first 6 months of life. J Pediatr (Rio J). 2004;80:99-105.

7. DeMayer EM. Preventing and controlling iron deficiency anaemia through primary health care: a guide for health administrators and programme managers. Geneva: WHO; 1989.

8. Domellöf M, Dewey KG, Lonnerdal B, Cohen RJ, Hernel O. The diagnostic criteria for iron deficiency in infants should be reevaluated. J Nutr. 2002;132:3680-86.

9. Souza AI, Filho MB, Ferreira LOC. Alterações hematológicas e gravidez. Rev Bras Hematol Hemoter. 2002;24:29-36 
10. Paiva AA, Rondó PHC, Pagliusi RA, Latorre MRDO, Cardoso MAA, Gondim SSR. Relação entre o estado nutricional de ferro de parturientes e seus recém nascidos. Rev Saúde Pública. 2007;41:321-7

11. Dube K, Schwartz J, Mueller MJ, Kalhoff H, Kersting M. Iron intake and iron status in breastfed infants during the first year of life. Clin Nutr. 2010;29:773-8

12. Global strategy for infant and young child feeding e The optimal duration of exclusive breastfeeding. Geneva: WHO; 2001.

13. Friel JK, Aziz K, Andrews WL, Harding S, Courage ML, Adams RJ. A doublemasked, randomized control trial of iron supplementation in early infancy in healthy term breast-fed infants. J Pediatr. 2003;143:582-6.

14. Yang Z, Lönnerdal B, Adu-Afarwuah S, Brown KH, Chaparro CM, Cohen $\mathrm{RJ}$, et al. Prevalence and Predictors of iron deficiency in fully breastfed infants at 6 months of age: Comparison of data from 6 studies. Am J Clin Nutr. 2009;89:1433-40.

15. Chaparro CM, Neufeld LM, Alavez GT, Cedillo REL, Dewey KG. Effect of timing of umbilical cord clamping on iron status in Mexican infants: a randomized controlled trial. Lancet. 2006;367:1997-2004.
16. Van Rheenen PF, Brabin BJ. A practical approach to timing cord clamping in resource poor settings. BMJ. 2006;333:954-8.

17. Van Rheenen PF, Gruschke S, Brabin BJ. Delayed umbilical cord clamping for reducing anaemia in low birthweight infants: implications for developing countries.Ann Trop Paediatr. 2006;26:157-67.

18. Baker RD, Greer FR. Committee on Nutrition American Academy of Pediatrics. Diagnosis and prevention of iron deficiency and irondeficiency anemia in infants and young children ( $0-3$ years of age). Pediatrics. 2010;126:1040-50.

19. Torres MAA, Braga JAP, Taddei JAAC, Nóbrega FJ. Anemia em lactentes de baixa renda em aleitamento materno exclusivo. J Pediatr (Rio J). 2006;82:284 288.

20. Sociedade Brasileira de Pediatria. Documento Científico. Nutrologia Anemia Carencial Ferropriva. Fevereiro; 2007. Available from: http://www.sbp.com. br/img/documentos/doc_anemia_carencial_ferropriva.pdf.

21. Greer FR. Orientação dietética para a prevenção da anemia por deficiência de ferro em lactentes no Brasil: é preciso algo mais. [Editorial] J Pediatr (Rio J). 2012;88:4-5 